\title{
Autologous Anti-CD19 CAR-expressing T Lymphocytes
}

National Cancer Institute

\section{Source}

National Cancer Institute. Autologous Anti-CD19 CAR-expressing T Lymphocytes. NCI

Thesaurus. Code C125691.

A preparation of autologous T-lymphocytes that have been genetically modified to express a chimeric antigen receptor (CAR) that targets the human tumor associated antigen (TAA) CD19, with potential immunostimulating and antineoplastic activities. Upon administration, autolog ous anti-CD19 CAR-expressing T lymphocytes bind to and induce selective toxicity against CD19-expressing tumor cells. CD19 antigen is a B-cell specific cell surface antigen expressed in all B-cell lineage malignancies. 